\section{China's Social Organisations after the Charity Law}

\section{Karla W. Simon \\ Holly Snape}

The passage of the Charity Law in May 2016 has made the legal environment for charities in China more complex. The new Law does represent an initial breakthrough in the transformation of the regulatory system for social organising and, on a deeper level, in the relations between society, government, Party, and market. However, it does not equalise the rules for all Chinese non-profit organisations and, crucially, it does not provide a basic social organisation law applicable to all types of non-profit entities. Why does this matter?
Many commentators have sought to simplify the legal environment in China after the passage of the Charity Law in May 2016 (National People's Congress 2016). But in our view that Law has made the legal environment more complex. The new Law does represent an initial breakthrough in the transformation of the regulatory system for social organising, and on a deeper level in the relations between society, government, Party, and market. However, it does not equalise the rules for all Chinese non-profit organisations (NPOs), and crucially it does not provide a basic social organisation law applicable to all types of non-profit entities. But why does this matter?

\section{What is a Social Organisation?}

To understand the need for a basic law for social organisations, first we need to get straight what social organisations are, and what charitable organisations are not. 'Social organisation' (shehui zuzhi)

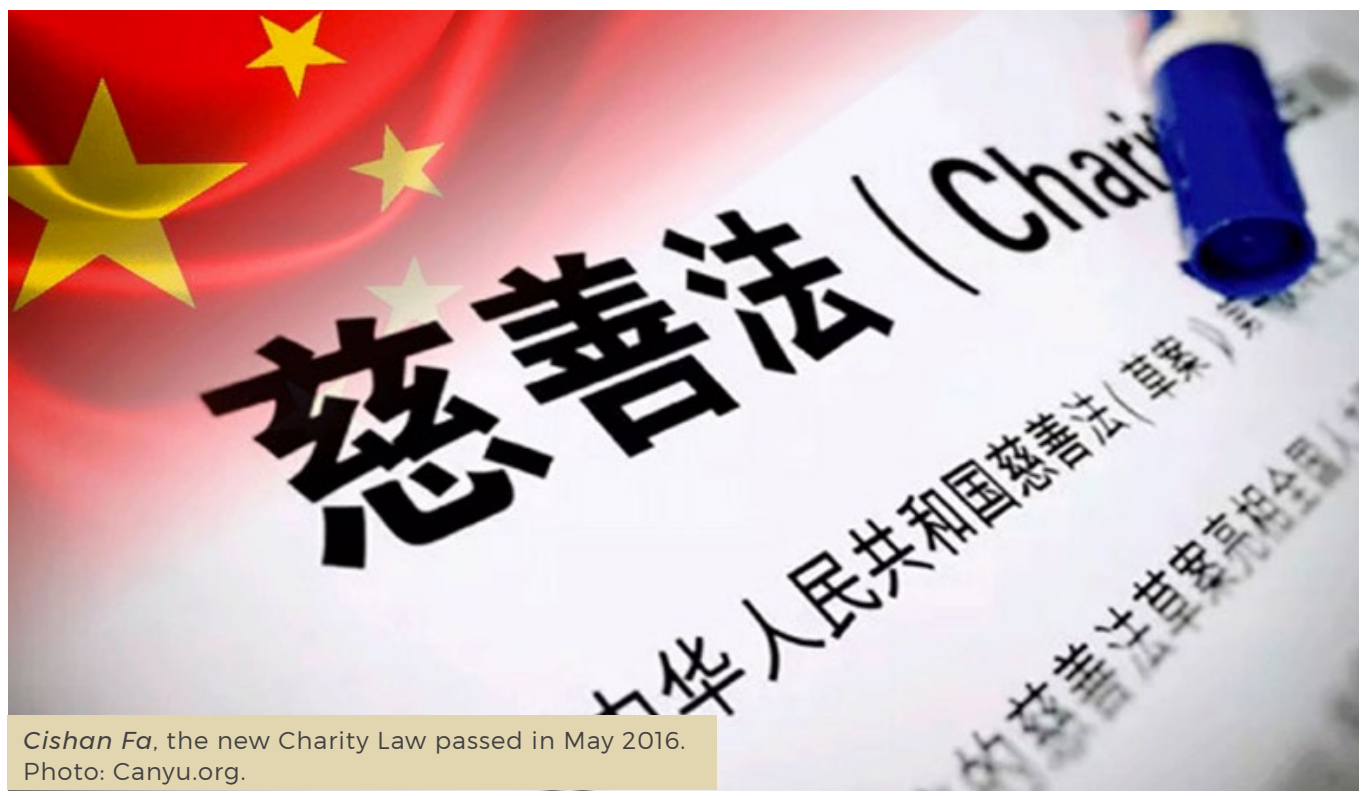


(hereafter SO) can be understood as a kind of blanket term used in official policy for all kinds of non-governmental NPOs. It covers the three legal forms that Chinese citizens are obliged to choose from to establish such an organisation: foundations (jijinhui), social groups (shehui tuanti), and social service organisations (NPC 2017) (shehui fuwu jigou). At present, it also covers citizeninitiated non-enterprise units (widely known by their abbreviated Chinese name 'minfei' (minban feiqiye danwei). The latter continues to be a legal form even though the Charity Law and the newly modified General Provisions of Civil Law (GPCL), passed by the NPC on 15 March 2017, replace it with 'social service organisations'. There are currently over three hundred and twenty thousand minfei already with legal status that have been placed in limbo since the passing of the Charity Law (State Council 2016). This is partly because the relevant administrative regulations are currently being revised-the latest draft of the new minfei regulations was released publicly in May-June 2016 to solicit comments (MCA 2016), but revisions have been ongoing for years and there is uncertainty as to when and what revisions will be made.

The term 'SO' also covers a new category'charitable organisation' (cishan zuzhi)created by the Charity Law. While the new GPCL makes the watershed adjustment of dividing legal persons into 'non-profit' and 'for-profit', charitable organisations are not among the four categories of organisations referred to as NPOs. 'Charitable organisation' does not represent a legal category in its own right. Instead it can be thought of as being a hallmark of an SO's ability to adhere to legal requirements related to accounting, transparency, and so on. To become a charitable organisation, a group must register as one of the legal forms of non-profit SOs, then apply for charitable accreditation. In other words, if we tier the new system ('new' after the GPCL), the
GPCL is the threshold system, a basic law on SOs would be the second tier (this does not yet exist), and the Charity Law would be the third tier.

The GPCL treats public service institutions (shiye danwei), foundations, social groups, and social service organisations as NPOs. The first of these, public service institutions, differ significantly from the others. They are not SOs, although it is intended that some will morph into them. Born of the socialist system built after the establishment of the People's Republic of China, public service institutions formed the public service arm of the government structure that all but subsumed society. With their deep links to government and their ability to monopolise resources and opportunities, their reform is essential to creating a competitive nonprofit market in which diverse and genuinely non-governmental organisations can thrive.

China's SOs work in education, healthcare, culture, science and technology, and sports and fitness, which are among the many fields covered explicitly in the broad definition of charity used in the Charity Law. But they also work in a vast range of other areas, on labour issues, in advocacy, legal services, and so on, none of which are covered by the Charity Law. While legislators and scholars involved in the legislative process for the Charity Law underlined the 'big' definition of charity as a legislative success and an important fundamental feature of the Law, many SOs cannot be squeezed into the definition of charitable organisations, no matter how 'big' that definition may be.

In implementation, while the Charity Law offers the opportunity to gain charitable status through accreditation to SOs that do fit its definition, there is already anecdotal evidence of SO leaders being reluctant to seek this charitable status for their organisations (Jin xia shuo shenme da shihua 2017). Thus, for myriad SOs, there is a gaping legislative hole. 


\section{Breaking Down the Old System of SO Regulation}

There is no doubt that the Charity Law is a landmark step toward breaking down the old system for regulating social organising. That system was characterised by a lack of clear boundaries between society, state, and the market, and the use of administrative powers to meddle in and control SOs combined with a failure to regulate effectively. At the Eighteenth National Congress of the Chinese Communist Party (CCP) in 2012, it was announced that China was to build 'an SO system in which government and SOs are separate, powers and obligations are clear, and autonomy is practiced in accordance with law' (Hu 2012, part seven). This is a powerful statement of intent, which has often been quoted in the Chinese literature to suggest that $\mathrm{SOs}$ will gain greater autonomy and be freed from government intervention (see, for example, Wang 2014). The Charity Law, if implemented fully, is a significant move in this direction, to a certain extent delineating boundaries and replacing administrative control with law-based regulation. In this sense, it is an important step in building a new model of governance.

The Charity Law moves toward direct registration for some SOs in a step that is basically a nationwide adoption of rules that had already been put into practice in a large number of provinces. It moves away from ex ante regulation to a system of ex post oversight connected to report filing, transparency, and accountabilityplacing new demands on organisations in these regards. These responsibilities do not come accompanied automatically with new rights. The Charity Law and its ancillary regulations make the right to fundraise from the public a possibility for SOs that gain charitable organisation status, albeit only through a further process of accreditation. This is a major step in levelling the playing field for some genuinely non-governmental organisations to compete in the non-profit market.

The new Law begins to swap opaque administrative management for a greater reliance on public oversight, and new ways of making this possible, such as with analysis of big data. There continue, however, to be exceptions and strong traces of the old way of thinking about how to achieve regulation. This is apparent for example in the Provisional Regulations on the Work of SO Registration and Management Bodies Related to Administrative Law Enforcement Using Talks (yuetan) released days after the passage of the Charity Law. Also, interestingly, some of the ancillary regulations that followed the passage of the Charity Law are actually related to all SOs and not just those with charitable organisation status, such as the Provisional Measures on SO Registration and Management Bodies' Receipt and Handling of Complaints and Accusations passed in August 2016, and the Guiding Opinion on Strengthening and Improving the Management of Pay in SOs issued in July of the same year. This shows the need to regulate all SOs and not just charitable organisations.

\section{Building a New System of Governance}

The Charity Law goes further toward enabling SOs to provide public services to the Chinese people in lieu of government. This means that government must delegate and outsource service provision through instruments set up at the local level (Simon 2013). Some provinces and municipalities will find it more comfortable to do this by contracts or grants, while others may wish to use vouchers, and other methods (Simon and Teets 2014). 
Allowing SOs to provide almost everything but the most basic of public services forms one part of the transformation of China's system of governance. Back in 2013, the Resolution of the Third Plenary Session of the Eighteenth Central Committee of the CCP announced that the 'overall aim of comprehensively deepening reform is to push ahead with the modernisation of China's governance system and capacity for governance' (Central Committee of the CCP 2013). But using law as a means to do this will only go so far unless the law itself goes further. A basic law for charities is not enough.

Two areas of reform given attention in Premier Li Keqiang's 2017 Government Work Report illustrate this well ( $\mathrm{Li}$ 2017). The first is the 'profound reform of government' as government steps up efforts to transform its own functions and delegate roles and powers to others. SOs, not just charitable organisations, are a key group to 'receive' these new roles and powers. A crucial top level policy document issued jointly in 2016 by the general offices of the CCP Central Committee and the State Council (2016)-an unprecedentedly high level document for the non-profit sectorlinks the government's transformation of functions directly to SO development. The 'Two-Office Opinion' (liangban yijian) as this document is known in Chinese, tells us that government will give priority to SOs in purchasing services related to safeguarding people's welfare, social governance, and industry regulation, and states the need for SOs to make innovations in social governance.

The second, directly related to the first, is the continued reform of public service institutions, the so-called shiye danwei. This reform goes back many years, but was underlined early in Xi Jinping's first term in office as an important task in transforming the functions of government. Looking back at the Resolution of the Third Plenary Session of the Eighteenth Central Committee, the stated intention was to "push publicly run public service institutions to clear up their relationships with their managing bodies and de-governmentalise (qu xingzhenghua), and 'push those public service institutions in the position to do so to transform into enterprises or SOs.'

What kind of SOs are these public service institutions supposed to transform into? Surely they cannot all be transformed into charities? And yet there is no basic law for SOs. This is not an easy issue as these institutions have complicated relationships with the state, involving a tangled web of different interests. Perhaps an even more knotty issue is that of the mass organisations (renmin tuanti), such as the All-China Federation of Trade Unions and the AllChina Women's Federation. But, these are critical reforms. In the market, state-owned enterprise reform is needed to level the playing field for businesses. In the third sector, public service institution reform is needed to allow the fair competition necessary to develop healthy SOs able to take on the roles and responsibilities of a transforming and downsizing government. 
This text is taken from Gilded Age: A Year of Chinese Labour, Civil Society, and Rights, Made in China Yearbook 2017, edited by Ivan Franceschini and Nicholas Loubere, published 2018 by ANU Press, The Australian National University, Canberra, Australia.

doi.org/10.22459/MIC.04.2018.19 